\title{
Upper Stage Liquid Propellant Rocket Engine: A Case Analysis
}

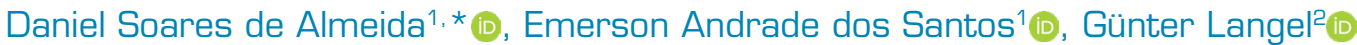

1.Departamento de Ciência e Tecnologia Aeroespacial - Instituto de Aeronáutica e Espaço - Subdiretoria de Projetos - São José dos Campos/São Paulo - Brazil 2.Aerospace Consulting - München/Bayern - Germany

*Corresponding author: dsa62@yahoo.com

\begin{abstract}
This paper provides an overview of the design and development process for the L75 liquid propellant rocket engine (LPRE) foreseen as upper stage of a satellite launch vehicle application. Emphasis is put on the choice of available technologies, an adequate operational cycle, and the most suitable propellant combination. Problems encountered during the development and resulting solution approaches are described. Furthermore, a survey of upper stages including their main performance data currently in operation worldwide is presented. Since economical constraints are more important today compared to previous developments schedule and cost figures and their drawbacks are investigated as well. Finally, a summary regarding the development status of the Brazilian L75 engine is reported.
\end{abstract}

Keywords: Liquid propellant rocket engine; Propulsion; Ethanol; System engineering; L75 engine.

\section{INTRODUCTION}

Liquid propellant rocket engines (LPREs) are mostly used within space transport compared to other chemical propellant solutions. They have higher specific impulse (Isp) than other chemical propulsion candidates, such as solids or hybrids. Liquid propellant rocket engines are characterized by substantial advantages. They offer a wide range of thrust, reignition and reuse capability as well as throttlability (Sutton 2006).

Liquid propellant rocket engines are used worldwide in application for expandable and reusable launchers and space vehicles. The option to verify their performance on ground by tests prior to launch is a key argument in view of risk mitigation, reliability assessments and cost overrun avoidance (Sutton 2006).

Today's commercial aspects in space transportation put high emphasis to combine performance and reasonable cost. All countries and parties involved in space business are undertaking any effort to achieve a strategic advantage for its own access to space. If Brazil really wants to enter this market, the L75 Engine for upper stage application project must take these aspects into account.

The goal of the paper is to present the design and development approach chosen as well as the discussion of problem areas encountered during the development process and to describe solution options. Furthermore, the paper discusses engineering, project management, schedule, and cost issues.

Received: Jul. 31, 2020 | Accepted: Nov. 25, 2020

Peer Review History: Double Blind Peer Review.

Section Editor: Alison Moraes

This is an open access article distributed under the terms of the Creative Commons license. 


\section{L75 ENGINE}

The L75 is an open cycle engine using the gas generator principle fed with the propellant combination liquid oxygen (Lox)/ethanol (Fig. 1). The development authority is the Brazilian Institute of Aeronautics and Space (IAE) located in São José dos Campos/São Paulo and supported by Brazilian Space Agency (AEB).

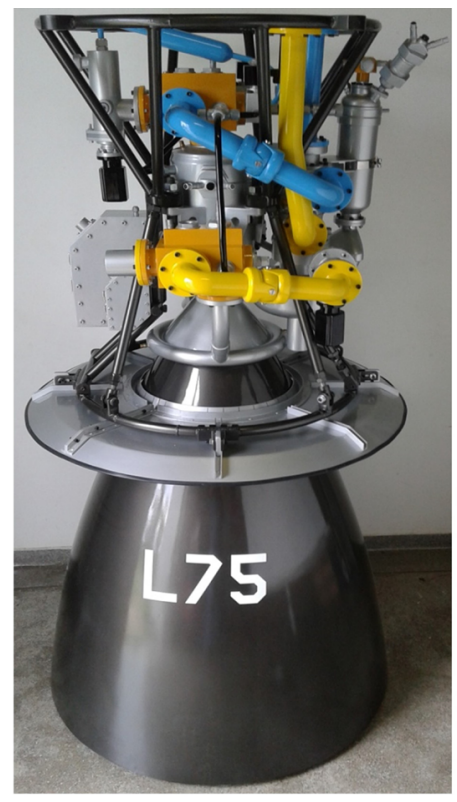

Figure 1. Mockup of L75 engine.

At the end of the 1990s, with the expectation of completing the VLS-1 project and its launching, the Brazilian National Space Activities Program - PNAE 98-2007 (AEB 1998) envisaged the development of a satellite launch vehicle, sized for commercial orbital application, the VLS-2. The IAE, as responsible for its development, presented a long-term training proposal whose first planned activity was a specialization course in liquid propulsion taught by Moscow Aviation Institute (MAI) professors, the course took place between 1997 and 1998, preparing the necessary human resources for obtaining the competence required to execute a LPRE project of up to $100 \mathrm{kN}$ of thrust, comprising design, manufacture, and operation in test benches.

The VLS-2 would have the capacity to launch satellites up to $900 \mathrm{~kg}$ in $2000 \mathrm{~km}$ equatorial orbit or $1000 \mathrm{~kg}$ in $1000 \mathrm{~km}$ heliosynchronous orbit. For these missions, on MAI's recommendation, a vehicle with all liquid stages and an upper stage with a modified RD-0109 was selected (Sutton 2006).

The PNAE 2005-2014 (AEB 2005) reaffirmed the need to enable Brazil in the area of liquid propulsion, which allowed the continuity of the activities of the IAE's Liquid Propulsion Laboratory and the advancement of the L75 Project. On the other hand, the PNAE 2012-2021 (AEB 2012) mentions the VLS-alpha for launching satellites with mass between 200 to $500 \mathrm{~kg}$ in low earth orbits consisting of the low part of the VLS-1 and a 75 kN LPRE (L75) equipping the upper stage.

Due to technological challenges and limited financial and human resources, there was a need for the IAE and AEB to realign the Brazilian launch vehicle development strategy and the VLS-1 Project ended in the late 2010s. However, recent study of launch vehicles with the capacity to place a payload of $450 \mathrm{~kg}$ in a circular orbit of $700 \mathrm{~km}$, using in the first and second stages the solid motor S50 (AEB 2020), which is under development, indicates the feasibility of using the L75 in a liquid stage, showing its versatility to meet a wide range of missions.

The engine shall develop a thrust of $75 \mathrm{kN}$ operating $400 \mathrm{~s}$ under vacuum conditions to accomplish the missions. Table 1 summarizes the L75 engine main characteristics. Propellant feeding to the combustion chamber shall be performed by a turbomachinery. A turbine fed by the exhaust gases of the gas generator drives the pumps. The turbomachinery is of a single shaft overhang design. Pyrotechnical devices shall provide combustion chamber and gas generator ignitions, as well as turbomachinery start-up. 
Table 1. L75 engine main characteristics.

\begin{tabular}{cc}
\hline Main parameters & Value \\
\hline Thrust in vacuum $(\mathrm{kN})$ & 75.0 \\
\hline Specific impulse in vacuum $(\mathrm{s})$ & 315 \\
\hline TC Lox flow $(\mathrm{kg} / \mathrm{s})$ & 14.10 \\
\hline TC ethanol flow $(\mathrm{kg} / \mathrm{s})$ & 8.85 \\
\hline Chamber pressure $(\mathrm{MPa})$ & 5.85 \\
\hline Nozzle area ratio $(-)$ & 147 \\
\hline GG pressure $(\mathrm{MPa})$ & 4.82 \\
\hline GG Lox pressure $(\mathrm{kg} / \mathrm{s})$ & 0.31 \\
\hline GG ethanol flow $(\mathrm{kg} / \mathrm{s})$ & 1.00
\end{tabular}

TC: Thrust chamber; GG: gas generator; Lox: liquid oxygen.

The L75 project development started in 2008 in Brazil. In 2011, the Brazilian Space Agency (AEB) and Germany's Space Administration (DLR) decided to extent the more than 40 years of successful Brazilian-German space cooperation with so far strong focus on sounding rockets to the field of liquid propulsion. Within the first project phase, work was focused on system studies and the design of the engine's main assemblies thrust chamber (TCA) and turbopump assembly (TPA), valves, regulators, and ignition devices.

\section{PRODUCT BREAK DOWN STRUCTURE}

The development logic applied is translated into product break down structures for project managing, cost control and performance tracking. Figure 2 shows a sketch of the product break down.

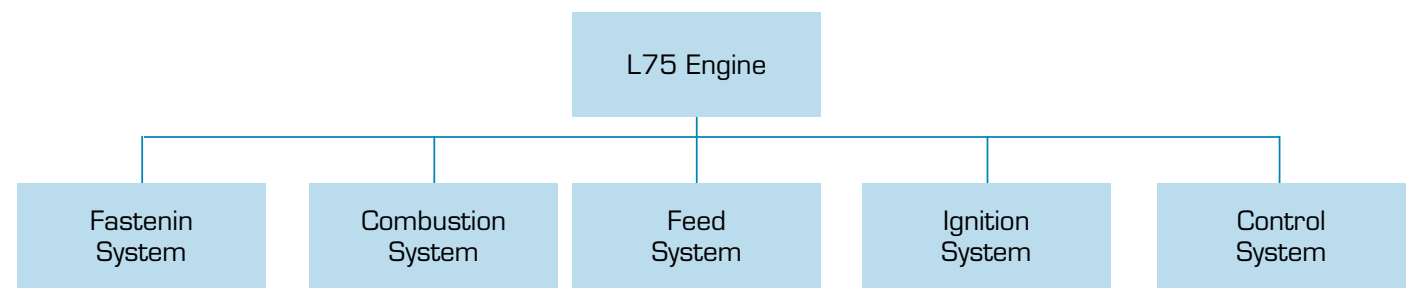

Figure 2. L75 engine product break down.

In the following the main tasks of the logic plan are described.

- The fastening system shall provide the mechanical frame to carry the loads and to transmit the thrust into the stage structure. It supports the fixation of all engine components and ensures to safeguard the engine hardware during transport, storage and handling.

- The combustion system consists of the thrust chamber and a gas generator. The thrust chamber components shall assure stable combustion and to deliver the required thrust. The gas generator shall power the turbine of the turbomachinery to supply the required mass flow into the combustion chamber. The thrust chamber assembly design consists of a regeneratively cooled combustion chamber with a copper alloy liner and a stainless-steel outer shell. The injector head contains 91 double swirl injection elements. The nozzle extension has two sections: a regeneratively and a radiation cooled.

- The feed system shall adjust propellant pressures in the fuel and oxidizer feed lines providing the correct conditions at thrust chamber and gas generator inlet. The feed system consists of turbopump, valves, regulators, and supply lines. 
- The ignition system shall ignite fuel-oxidizer mixture in the combustion chamber. The energy is provided by pyrotechnic charges.

- The control system shall manage the engine operation in response to the launcher vehicle commands. It controls all engine operations. Main tasks are the initiation of, e.g., engine purging, chill-down, ignition, steady state operation, and shutdown. The control system also provides the data for the communication with the vehicle and ground support.

\section{PROPELLANT SELECTION}

A first classification of the propellants can be done by evaluating their characteristic velocity and thrust coefficient. Therefore, a high combustion temperature, a low isentropic exponent as well as a low molecular weight of the exhaust gases is preferable. The physical properties of the propellants are driver for engine cycle selection and launcher design for achieving the optimal specific impulse as performance requirement. Figure 3 shows the theoretical specific impulse for various propellant combinations as function of engine mixture ratio for a combustion pressure of 100 bar and an area ratio $(\mathrm{Ae} / \mathrm{At})$ of 45 .

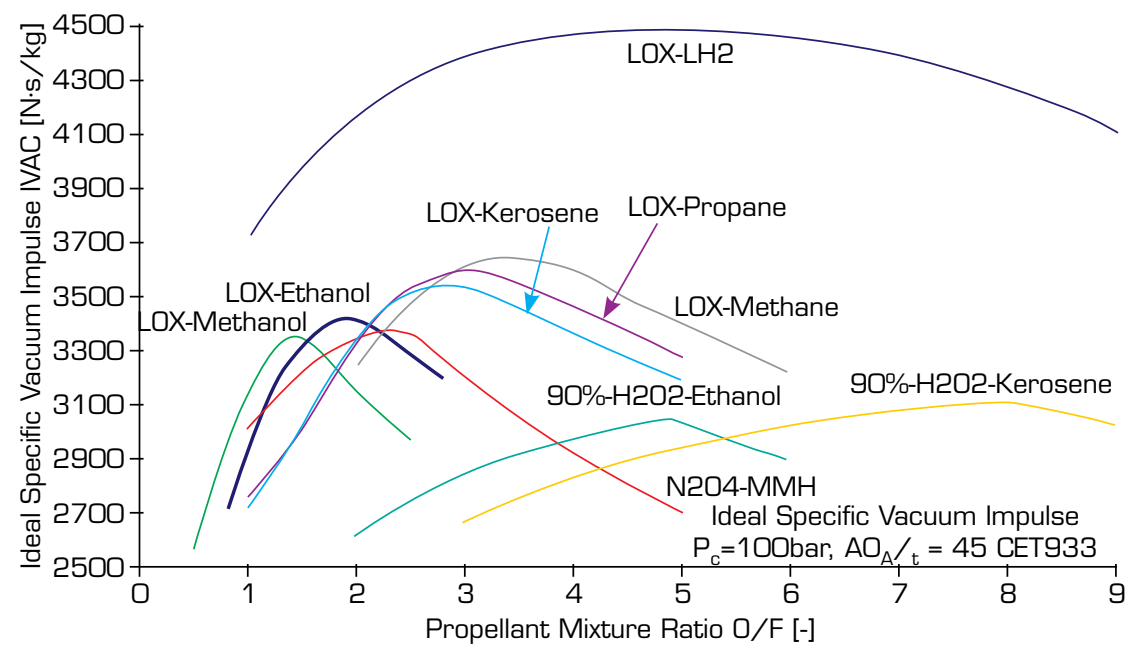

Figure 3. Main propellant pairs for a LPRE (Ernst, 2014).

The results of Fig. 3 allow distinguishing propellant combination performance into three classes. The highest performance delivers Lox $/ \mathrm{LH}_{2}$ followed by the hydrocarbons whereas the specific impulse values decrease with higher carbon content. Storable propellants show the lowest performance.

Besides small deficiencies in performance, Lox-ethanol propellant combination has the following advantages: availability in Brazil, nontoxicity, environmentally clean, low cost and does not suffer pyrolysis or produce significant soot at high temperatures inside the cooling channels of the regenerative cooling combustion chamber (Haeseler et al. 2000).

Furthermore, others factors supported the decision to use this propellant combination, such as the LPRE L5 tests in Brazil with Lox-ethanol; the Lox-ethanol know-how of German industry based on their past "green" activities with Rocketdyne; the know-how within DLR Lampoldshausen based on the Lox-ethanol steam generators for altitude testing; and the last but not least the feasibility of L75 sub-system or system hot-fire testing in Lampoldshausen due to environmental regulations (Almeida et al. 2016). In addition to these factors, a vehicle using a stage with Lox-ethanol instead of Lox-kerosene satisfies mission's requirements planned for the L75. 


\section{OPERATIONAL CYCLE}

Basically, there are two options to pressurize propellants for LPRE application.

1. Tank pressurization by external high-pressure gas (pressure-fed systems);

2. Turbomachinery.

The thrust level of pressure-fed engines is limited by available tank technology. An example is the AESTUS engine of ARIANE $5 \mathrm{G}$ or the space shuttle orbital maneuvering system (Haidn 2008). Pump-fed engines apply the principle of a turbocharger to pressurize the propellants and Fig. 4 presents the main options. The open or gas generator cycle is chosen for L75.

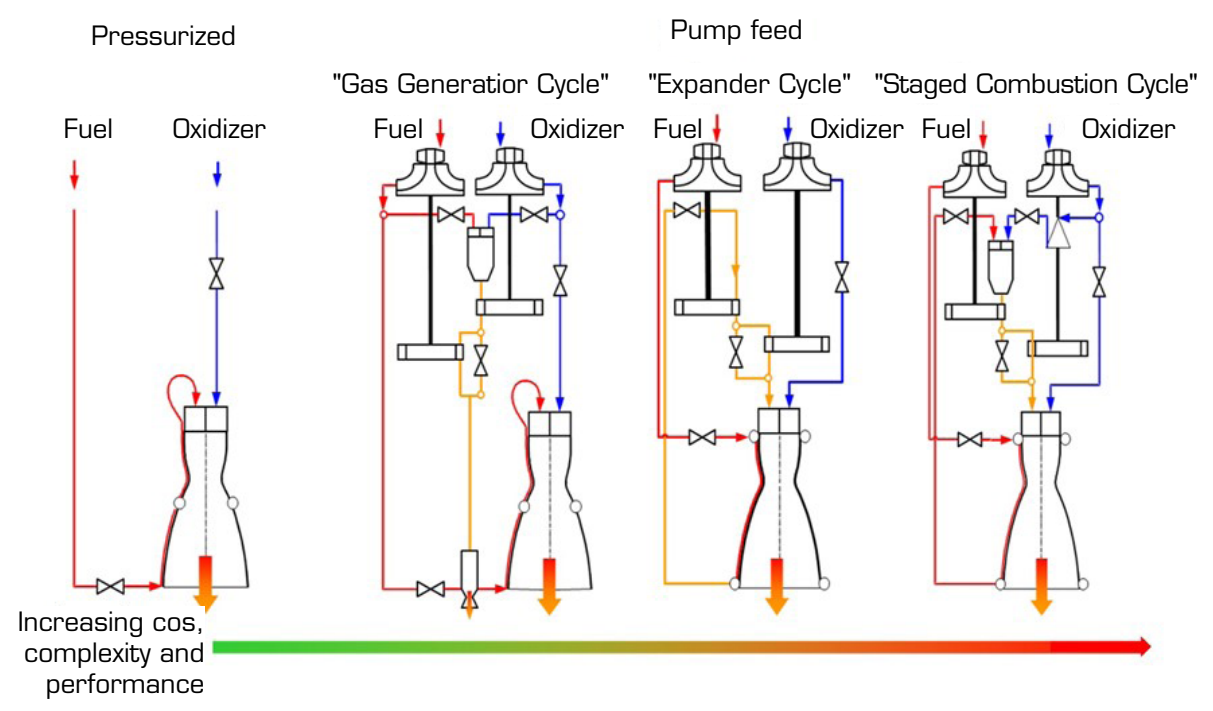

Figure 4. Main options to pressurize propellants - adapted from Haidn (2008).

The open cycle offers the lowest overall cost and provides a low engine structural mass because of the lower internal pressure usually seen in engines with a gas generator. However, this cycle configuration gives somewhat lower performance than the closed or expander cycle, which is more complicated in scheme, design, manufacturing, and testing (Torres et al. 2009).

The expander cycle uses the fuel to cool the engine's combustion chamber, picking up heat and changing phase for gaseous before entering the turbine. The heated fuel used for cooling then powers the turbine that drives the fuel and oxidizer pumps before being injected into the combustion chamber and burned in a combustion process. The VINCI is an expander cycle upper stage engine with an increased performance and multiple ignition specification, which is typical of what is currently required to enlarge the scope of missions and increase the capability of heavy expandable satellite launchers and is more tolerant to system failure, also contributes to improve reliability (Caisso et al. 2009).

In the closed or staged combustion cycle, the hot gases from the gas generator goes to the main engine chamber after driving the turbine, and it was developed for high-pressure engines necessary for ascent stages and boosters. This configuration permits high pressure leading to more compact engines with better sea level specific impulse. Incidentally, the staged combustion provides another advantage: As the turbine exhaust is gaseous, the main chamber combustion is consequently very stable (gas/liquid combustion) (Caisso et al. 2009).

The evolution from the pressurized cycle to the most sophisticated ones was driven, basically, by the Cold War, where competition for military and space supremacy justified large government budgets, if compact, low-weight, high-performance engines were obtained. The IAE's strategy was originally formulated to proceed through gas generator cycle; it is a less complex technology, when compared to the others and in current use around the world.

Table 2 shows a summary of the main advantages and disadvantages of these three cycles. 
Table 2. Comparison among different engine cycles.

\begin{tabular}{|c|c|c|c|}
\hline & Gas Generator Cycle & Stage Combustion Cycle & Expander Cycle \\
\hline Advantages & $\begin{array}{c}\text { Interface between the combustion } \\
\text { chamber and turbopump less } \\
\text { complex. } \\
\text { Independent development of } \\
\text { chamber and turbomachinery } \\
\text { possible. } \\
\text { Moderate discharge. }\end{array}$ & $\begin{array}{l}\text { High chamber pressure combined } \\
\text { with high specific impulse } \\
\text { possible. } \\
\text { Compact turbine design. } \\
\text { No separate turbine exhaust duct. }\end{array}$ & $\begin{array}{l}\text { Low complexity of the engine } \\
\text { design. } \\
\text { Ignition only for main chamber. } \\
\text { Low turbine inlet temperature. }\end{array}$ \\
\hline Disadvantages & $\begin{array}{l}\text { Impulse loss due to gas generator } \\
\text { operation. } \\
\text { Low turbine efficiency. } \\
\text { Additional performance loss due } \\
\text { to higher mixture ratio. }\end{array}$ & $\begin{array}{l}\text { Due to complex interfaces only } \\
\text { combined development of chamber } \\
\text { and turbomachinery is possible. } \\
\text { High discharge pressure. } \\
\text { Complex engine ignition. }\end{array}$ & $\begin{array}{l}\text { Chamber pressure < } 100 \text { bar. } \\
\text { Due to complex interfaces only } \\
\text { combined development of chamber } \\
\text { and turbomachinery is possible. } \\
\text { High discharge pressure. }\end{array}$ \\
\hline
\end{tabular}

\section{UPPER STAGES USING LPRE}

The task of an upper stage or orbital stage (second, third and sometimes even fourth) of a launch vehicle is to deliver the payload into a defined orbit. Beside its propulsion system, an upper stage contains all necessary electronics to control and to ensure proper function of flight as well as navigation and communication with the flight control center on Earth (avionics of the launcher as flight computers, navigation, guidance, control system, communications systems, and flight termination).

Typically, the propulsion systems and thus the rocket engines are tailored to meet the specific requirements of the launching and its mission. As consequences, any improvement or modification of the engine has a significant impact on the entire launch system. Table 3 summarizes main performance data of the nowadays-operational upper stage equipped with LPREs around the world.

Upper stage engines can be gimbaled for pitch and the reaction control system could provide yaw control while roll control could be provided by the reaction control system. The reaction control system is also used during coast periods and to re-orient the vehicle for spacecraft separation. All these capabilities allow the upper stage accesses a variety of orbits including geostationary transfer orbit, geosynchronous orbit, escape trajectories and all types of lower orbits. The upper stage is deorbited after orbital unit separation to conduct a targeted re-entry for disposal of the rocket.

Since upper stage engines operate at high altitudes where drag losses are not as important as for the first's stages and booster engines, special attention is focused on the specific impulse and low mass ratio because mainly these variables enable more embedded payload for a mission. Additionally, turbopump allows the starting procedures with the possibility of engine restart, at engine nominal pressure much more moderate (in the range of 30-60 bar) and the complexity of the feed cycle limited to the gas generator or the bleed/expander cycle (Zandbergen 2000). Typical vacuum specific impulse levels achieved for these engines are in the range of 320-450 s and mass ratio in the range of 0.85-0.92 (Kessaev 1997).

As the upper stage goes into orbit, every reduction of its structural mass increases the payload capability. Thus, the structural efficiency (given by the mass ratio) must be the maximum bringing great challenges in both design and manufacturing issues. Figure 5 displays the relation between the mass ratio (structural efficiency) and specific impulse (energetic efficiency) for upper stages equipped with LPRE. Each point in the figure represents an upper stage engine described in the Table 3.

From Fig. 5 it is possible to classify the stages into three main groups:

Group I presents upper stages of the highest technology. It represents the last development phase of any space program and the state-of-the-art in liquid propulsion, present higher structural and energetic efficiency; it uses fully cryogenic propellants $\left(\mathrm{LH}_{2}\right.$ and Lox). The most efficient engines, in this group, are those using close or expander cycles. 
Table 3. List of operational upper stage equipped with LPRE by country.

\begin{tabular}{|c|c|c|c|c|c|c|c|c|c|c|c|c|}
\hline Country & $\begin{array}{l}\text { Launch } \\
\text { vehicle }\end{array}$ & $\begin{array}{l}\text { Upper } \\
\text { stage } \\
\text { Engine }\end{array}$ & $\begin{array}{c}\text { Engine } \\
\text { Cycle }\end{array}$ & Propellants & $\begin{array}{l}\text { Mixture } \\
\text { ratio }\end{array}$ & $\begin{array}{c}\text { Thrust } \\
\text { [kN] [Vac.] }\end{array}$ & $\begin{array}{l}\text { Spec. } \\
\text { impulse } \\
\text { [s] (Vac.) }\end{array}$ & $\begin{array}{c}\text { Chamber } \\
\text { pressure } \\
\text { [MPa] }\end{array}$ & MR & $\begin{array}{c}\text { Dry mass } \\
{[\mathrm{kg}]}\end{array}$ & $\begin{array}{l}\text { Propellant } \\
\text { mass [kg] }\end{array}$ & Remark \\
\hline \multirow{3}{*}{ China } & $\begin{array}{l}\text { Long March } \\
\text { 3A }\end{array}$ & YF-75 & Open & $\mathrm{Lox} / \mathrm{LH}_{2}$ & 5.1 & 78.5 & 431 & 3.76 & 0.87 & 2740 & 20933 & 2 chambers \\
\hline & $\begin{array}{l}\text { Long March } \\
5\end{array}$ & YF-75D & Expander & $\mathrm{Lox} / \mathrm{LH}_{2}$ & 6.0 & 88.26 & 442 & 4.1 & 0.89 & 3400 & 26500 & 2 chambers \\
\hline & $\begin{array}{c}\text { Long March } \\
7\end{array}$ & YF-115 & Closed & Lox/RP-1 & 2.5 & 176.5 & 341.5 & 12 & 0.92 & 6000 & 65000 & 4 chambers \\
\hline \multirow{2}{*}{ Europe } & Ariane 5 ES & Aestus & Pressure-fed & $\begin{array}{l}\mathrm{N}_{2} \mathrm{O}_{4} / \\
\mathrm{MMH}\end{array}$ & 1.9 & 29.6 & 324 & 11 & 0.87 & 1275 & 10000 & \\
\hline & $\begin{array}{c}\text { Ariane } 5 \\
\text { ECA }\end{array}$ & HM-7B & Open & $\mathrm{Lox} / \mathrm{LH}_{2}$ & 5.0 & 62.7 & 444.6 & 3.7 & 0.87 & 2100 & 14400 & \\
\hline \multirow{3}{*}{ India } & PSLV & PS-4 (L-2-5) & $\begin{array}{l}\text { Pressure } \\
\text { fed }\end{array}$ & $\begin{array}{l}\mathrm{N}_{2} \mathrm{O}_{4} / \\
\mathrm{MMH}\end{array}$ & $?$ & 7.4 & 308 & 8.4 & 0.68 & 920 & 2000 & 2 chambers \\
\hline & GSLV Mk.II & ICE [CE-7.5] & Closed & $\mathrm{Lox} / \mathrm{LH}_{2}$ & $?$ & 73.5 & 454 & 5.8 & 0.84 & 2500 & 12800 & \\
\hline & GSLV Mk.III & CE-2O & Open & $\mathrm{Lox} / \mathrm{LH}_{2}$ & 5.05 & 200 & 443 & 6.0 & 0.86 & 5000 & 28000 & \\
\hline $\begin{array}{l}\text { North } \\
\text { Korea }\end{array}$ & Unha & $?$ & $\begin{array}{l}\text { Pressure } \\
\text { fed }\end{array}$ & $\begin{array}{l}\mathrm{N}_{2} \mathrm{O}_{4} / \\
\text { UDMH }\end{array}$ & $?$ & 5.4 & 270 & $?$ & 0.80 & 200 & 800 & \\
\hline Japan & $\mathrm{H}-\mathrm{II}$ & LE-5B & Expander & $\mathrm{Lox} / \mathrm{LH}_{2}$ & 4.5 & 137 & 447 & 3.58 & 0.85 & 2930 & 16600 & \\
\hline \multirow{10}{*}{ Russia } & Angara 1.2 & RD-0124A & Closed & Lox/RP-1 & 2.34 & 294.3 & 359 & 15.7 & 0.92 & 2355 & 25400 & \\
\hline & Angara A7 & RD-0146D & Expander & $\mathrm{Lox} / \mathrm{LH}_{2}$ & 6.0 & 68.6 & 463 & 6.0 & 0.85 & 3880 & 26500 & \\
\hline & Proton-M/ & RD-0213 & Closed & $\begin{array}{l}\mathrm{N}_{2} \mathrm{O}_{4} / \\
\text { UDMH }\end{array}$ & 2.6 & 582 & 325 & 14.7 & 0.91 & 4185 & 46562 & Third stage \\
\hline & Briz-M & $\begin{array}{c}\text { S5.98 } \\
\text { (14D30) }\end{array}$ & Open & $\begin{array}{l}\mathrm{N}_{2} \mathrm{O}_{4} / \\
\text { UDMH }\end{array}$ & 2.0 & 19.62 & 328.6 & 9.8 & 0.89 & 2370 & 19800 & Upper stage \\
\hline & Rockot & RD-0235 & Closed & $\begin{array}{l}\mathrm{N}_{2} \mathrm{O}_{4} / \\
\text { UDMH }\end{array}$ & ? & 240 & 320 & 17.5 & 0.88 & 1500 & 10700 & \\
\hline & Soyuz FG & RD-0110 & Open & Lox/RP-1 & 2.2 & 74.5 & 326 & 6.8 & 0.90 & 2410 & 25300 & 4 chambers \\
\hline & Soyuz 2-1B & RD-0124 & Closed & Lox/RP-1 & 2.6 & 73.6 & 359 & 16.2 & 0.92 & 2355 & 25400 & 4 chambers \\
\hline & Zenit-3SL & RD-58M & Closed & Lox/RP-1 & 2.48 & 83.4 & 349 & 7.7 & 0.88 & 2140 & 15220 & \\
\hline & & RD-120 & Closed & Lox/RP-1 & 2.6 & 833 & 350 & 16.3 & 0.91 & 8307 & 82487 & \\
\hline & Zenit-3SLBF & S5.92 & Open & $\begin{array}{l}\mathrm{N}_{2} \mathrm{O}_{4} / \\
\text { UDMH }\end{array}$ & ? & 19.85 & 331 & 9.8 & 0.89 & 1320 & 10461 & \\
\hline \multirow{5}{*}{ USA } & $\begin{array}{l}\text { Delta II } \\
7320\end{array}$ & AJ-10-118K & $\begin{array}{l}\text { Pressure } \\
\text { fed }\end{array}$ & $\begin{array}{c}\mathrm{N}_{2} \mathrm{O}_{4} / \\
\text { Aerozine }\end{array}$ & 1.9 & 43.4 & 319 & 8.9 & 0.86 & 950 & 6000 & \\
\hline & $\begin{array}{c}\text { Delta IV } \\
\text { Heavy }\end{array}$ & RL-10B-2 & Expander & $\mathrm{Lox} / \mathrm{LH}_{2}$ & 5.88 & 110 & 464 & 2.4 & 0.87 & 3490 & 27220 & \\
\hline & Atlas V & RL-10C & Expander & $\mathrm{Lox} / \mathrm{LH}_{2}$ & 5.9 & 101.8 & 449.7 & 2.4 & 0.90 & 2243 & 20830 & \\
\hline & Electron & Rutherford & $\begin{array}{c}\text { Electric } \\
\text { Pump-fed }\end{array}$ & Lox/RP-1 & $?$ & 22 & 333 & $?$ & 0.90 & 250 & 2150 & \\
\hline & Falcon 9 & Merlin 1D & Open & Lox/RP-1 & 2.3 & 934 & 348 & 9.7 & 0.96 & 4000 & 107500 & \\
\hline Brazil & & L75* & Open & Lox/Ethanol & 1.6 & 75 & 315 & 5.9 & 0,85 & 1060 & 6000 & \\
\hline
\end{tabular}

MR: Mass ratio $\frac{M_{p}}{M_{d}+M_{p}}$; Mp: Propellant mass; Md: Dry mass; RP-1: Rocket kerosene; *In development phase. 


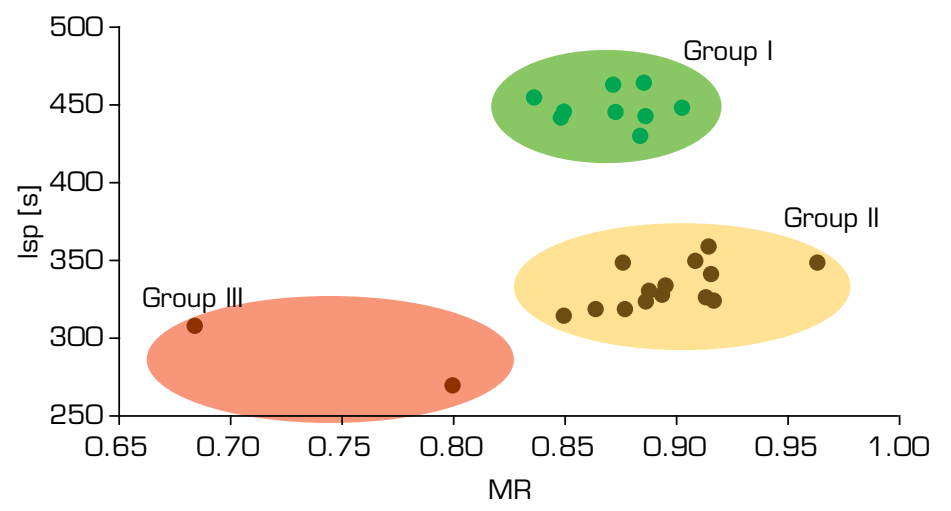

Figure 5. Mass ratio (MR) and specific impulse (Isp) for upper stages equipped with LPRE.

In Group II, the stages have higher structural efficiency and intermediated energetic efficiency, the engines with greater efficiency are those that use Lox and RP-1 as propellant in the closed cycle following by the open or pressure-fed cycle. The engines that use $\mathrm{N}_{2} \mathrm{O}_{4}$ and hydrazine derivatives show lower specific impulse compared with Lox and RP-1 pair, but these propellants have the advantage of being noncryogenic and self-ignitable. In this group, two configurations should be commented: first, the upper stage of the Electron uses the Rutherford engine powered by electric pumps, unique with this cycle in operation, presenting high structural and energetic efficiency. The second, the upper stage of the Falcon 9 vehicle uses the open-cycle Merlin 1D engine, which despite the use of conventional technologies, the information obtained from the manufacturer, shows high energetic and structural efficiency. Figure 6 shows the relation between mass ratio and specific impulse for Group II. As the L75 (highlighted in the Fig. 6) is in development process - technology readiness levels (TRL) 3, the mass optimization of both the stage and the engine has not yet been performed, for example the masses of the engine components are those of the development models, therefore the values presented for both MR and Isp are very conservative.

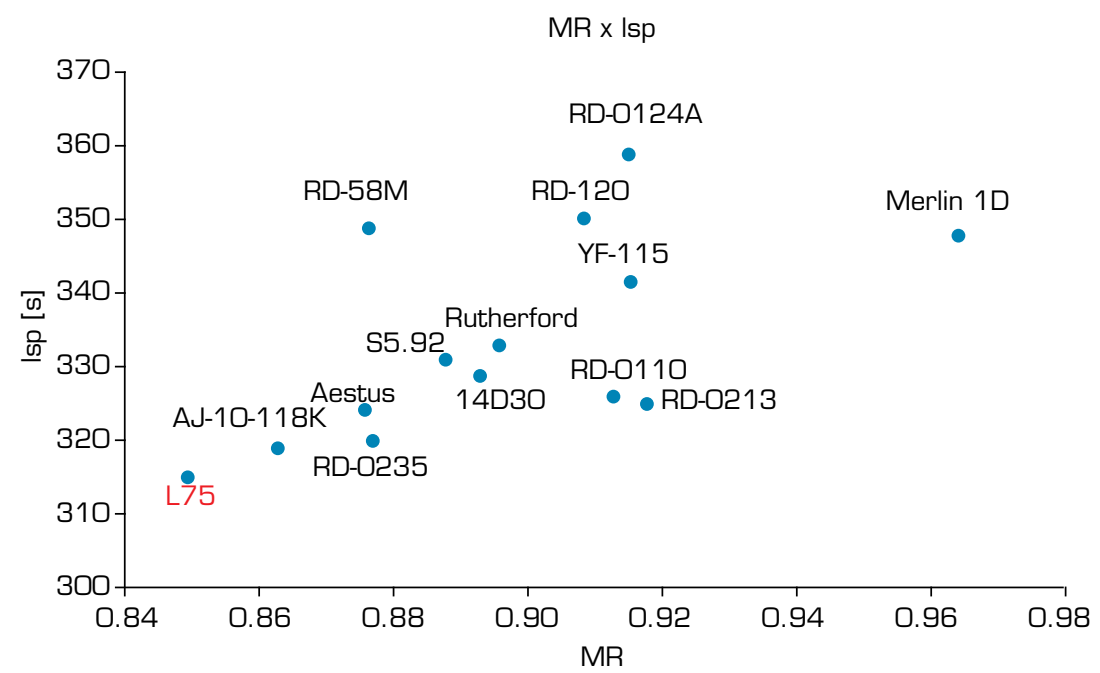

Figure 6. Relation between mass ratio and specific impulse for Group II.

Group III includes upper stages with pressure-fed cycle which, as a result, show low energetic and, because of the pressurized tanks with thick walls to withstand the minimum pressures required by the engines, show low structural coefficients, using $\mathrm{N}_{2} \mathrm{O}_{4}$ and hydrazine derivatives as a propellant. Typically, developers who are taking their first steps in space technology choose this cycle.

Due to the need to present high energetic and structural efficiencies combined with high reliability, the development of an upper stage consumes a large amount of time, financial and human resources of a space program. 
In these contexts, the L75 project had the following strategic guidelines from the Brazilian National Space Activities Program (PNAE):

- Expand and consolidate the competence in research, development and innovation in the aerospace area to meet the Brazilian challenges;

- Provide the adequate infrastructure for scientific and technological development, enabling Brazil to build LPRE stages for launcher vehicles;

- Meet the needs and demands of Brazil in the space area;

- Promote the training and establishment of human resources for Brazil;

- It would be a flexible rocket engine that can serve the various configurations of a launch vehicle;

- It would pave the way for the future development of engines with low mass ratio and high specific impulse;

- It would enable fundraising by providing rocket engine component testing services in the test infrastructure available and provided for the project;

- It would use ethanol as fuel, which is ecologically sustainable, less polluting than fuels used by other countries and available abundantly in Brazil;

- Enable the expansion of international partnerships, such as the one already in place with DLR, and with other countries, prioritizing the joint development of technological and industrial projects of mutual interest;

- It would allow the continuity of the participation of universities and research institutions in activities of interest of the space area;

- Encourage the training and development of talent specializing in various skills in space science and technology;

- The LPRE stage applied to a satellite launch vehicle would expand the provision of satellite launch services to Brazil and abroad.

\section{LPRE COST AND SCHEDULE APPROACH}

This section addresses the cost and schedule approach and shows the practices in estimating the financial and planning progress. According to project management, before the estimation of schedule and cost, the definition of its stated objective or mission must be defined. Knowing what will be done, the work packages are structured through the work breakdown structure and, therefore, the deadlines and related costs are defined. The life cycle cost estimating of a project must cover all costs involved from design, development, manufacturing, procurement, testing, production, operation, maintenance, and disposal. The costs are handled by the systems engineering team to know whether the new system meets the design requirements at a reasonable total cost and at a feasible execution time (Halligan 2016).

The project cost estimate can be made by comparing the cost from similar projects, considering the specific conditions, human resources, technical and technological limitations for the development of each project. Cost estimation is a critical activity for public or private companies because estimation errors can greatly impact the credibility and long-term viability of an organization. Estimating costs is a necessary activity to plan a budget to develop a system; to prepare a bid or proposal on the project to be developed; to negotiate the cost for a system and to provide a baseline to track and manage actual costs (Parnell et al. 2011).

Based on Parnell et al. (2011), twelve steps should be taken to develop cost estimates for a project:

- Develop the project breakdown structure;

- Elaborate the schedule with the planned work activities;

- Restore and organize historical data;

- Develop and use cost estimation relationships;

- Develop and use production learning curves;

- Identify categories with project-specific skills, skill levels, and labor costs;

- Develop estimates of working hours and material acquisition;

- Develop estimates of general and administrative expenses; 
- Apply correction factors due to inflation and increased costs;

- Compute the estimated total costs;

- Analyze and adjust the cost estimate;

- Publish and present the estimated costs.

Schedule planning determines the deadlines for each activity, resources, and duration through project closure. Based on PMBOK (PMI 2013), key concepts for understanding the time management processes of a project are: work packages (include the tasks to carry out the project until the closure), resources (refer to the specialized human resources, equipment, services, suppliers, materials, budgets or funds), duration (refers to the required time to complete a task or activity, not including holidays or other rest periods) and the time estimation (probable outcome of the whole project).

Depending on the availability of the industrial technology and research centers, the development of liquid propulsion technology may be faster or slower (between 6 and 15 years). If the efforts are concentrated on a single line of development may mean less time to achieve the mastery of technology. Government engagement and support from the public and private sectors is critical (Zandbergen, 2000; Niwa \& Yoshino, 1997).

Table 4 shows the history and planning for the development of the liquid propulsion technology at IAE. The total investment from 1997 until 2017 was around US\$ 20 million, and for conclusion of the project (Phase 2 and 3) the expected investment would be US\$ 60 million in net present value.

The development life cycle phasing presented in Table 4, according to ECSS-M-ST-10C was divided into four main phases:

- Phase 0: Mission identification and feasibility (concept);

- Phase 1: Preliminary design (development);

- Phase 2: Detailed design (engineering);

- Phase 3: Qualification.

Due to budget restrictions, the manufacturing and test of hardware during Phase 0 were absent. Phase 1 contemplates the manufacturing and tests of the thrust chamber, turbopump and gas generator, valves and regulators and control system development models. For the next two phases development models, engineering models and qualification models on engine level are considered to be necessary for conclusion.

Table 4. History and planning for the development of the liquid propulsion technology at IAE.

\begin{tabular}{cc}
\hline Project Phase & Activities \\
Phase 0 & Moscow Aviation Institute (MAl) course. \\
TRL 2 & Liquid Propulsion Professional Master's Degree. \\
Classroom material and MAl atlas (data collection). & Development of L1 (Santos et al. 2011), L5, L15, SAMF. \\
Feasibility, selection of solution to be developed. \\
US $\$$ Systems Engineering and Preliminary Design (SRR).
\end{tabular}

Despite the first investments in liquid propulsion in Brazil occurred in the 1990s, due to budget limitations and consequent changes in the National Space Activities Program (PNAE), there were several postponements in the implementation of L75 Project, which, in fact, only started in late 2012 with a financial contribution from AEB in the order of US\$ 12 million. 
With this financial contribution, in the period from 2012 to 2017, it was possible to hire specialists, most of whom came from the master's program in liquid propulsion, detail the designs of the engine components and test benches and hire companies to manufacture the engine components and some test benches (adequacy the $20 \mathrm{kN}$ test bench for testing subscale chambers and gas generator, implantation of the turbine and pump full scale capability test bench with model and cryogenics fluids and installation of the ethanol line at P8).

In addition, with the structuring of the team and financial resources for the project, it was possible to establish a partnership with DLR, which is extremely important, not only because it allows access to the P8 test stand, capable of testing the L75 full scale combustion chamber, but also to have access to liquid propulsion experts and component suppliers not available in Brazil. To carry out chamber testing campaigns in Lampoldshausen and to develop components for the German turbine and pumps, the DLR invested an amount in the order of US\$ 4 million.

The planning for the period from 2018 to 2022 was for the engineering models manufacture, construction of the $100 \mathrm{kN}$ test bench and carrying out subsystem tests at the referred test bench, with an estimated cost of US\$ 40 million. The last phase of the project would include the qualification of the engine in the $100 \mathrm{kN}$ test bench, with an estimated cost of US\$20 million. Due to the lack of financial resources, the project was suspended. Consequently, DLR also did not make resources available.

\section{LPRE RELIABILITY}

Reliability of engines and stages is achieved through testing, including operational launches in real environments. Table 5 presents the reliability for space launch vehicles, commercial jet airliners and general aviation. Figure 7 shows the number of tests and reliability for developed engines.

Table 5. Demonstrated reliability figures: air and space transportation.

\begin{tabular}{ccc}
\hline Space launch vehicles & Commercial jet airliners & General aviation \\
\hline $91.7 \%$ & $99.99983 \%$ & $99.998 \%$ \\
\hline $\begin{array}{c}\text { Western and Eastern launch vehicles } \\
\text { analyzed, with 4404 cumulated launches, } \\
\text { including 366 catastrophic failures (loss } \\
\text { of vehicle) (Langel, 2018) }\end{array}$ & $\begin{array}{c}\text { Evaluated for aircraft manufactured in } \\
\text { western world with MGLOW }>30 \text { tons: } \\
745 \text { loss of vehicle (1959 - 2005), } \\
\text { with 444 million commercial departures } \\
\text { (Boeing, 2006) }\end{array}$ & $\begin{array}{c}2001 \text { US Figures: 349 loss of vehicles, } \\
\text { with 25.4 million flight hours, assumed } \\
\text { average flight time 1.5 h / flight } \\
\text { (Aviation, 2001) }\end{array}$ \\
\hline
\end{tabular}

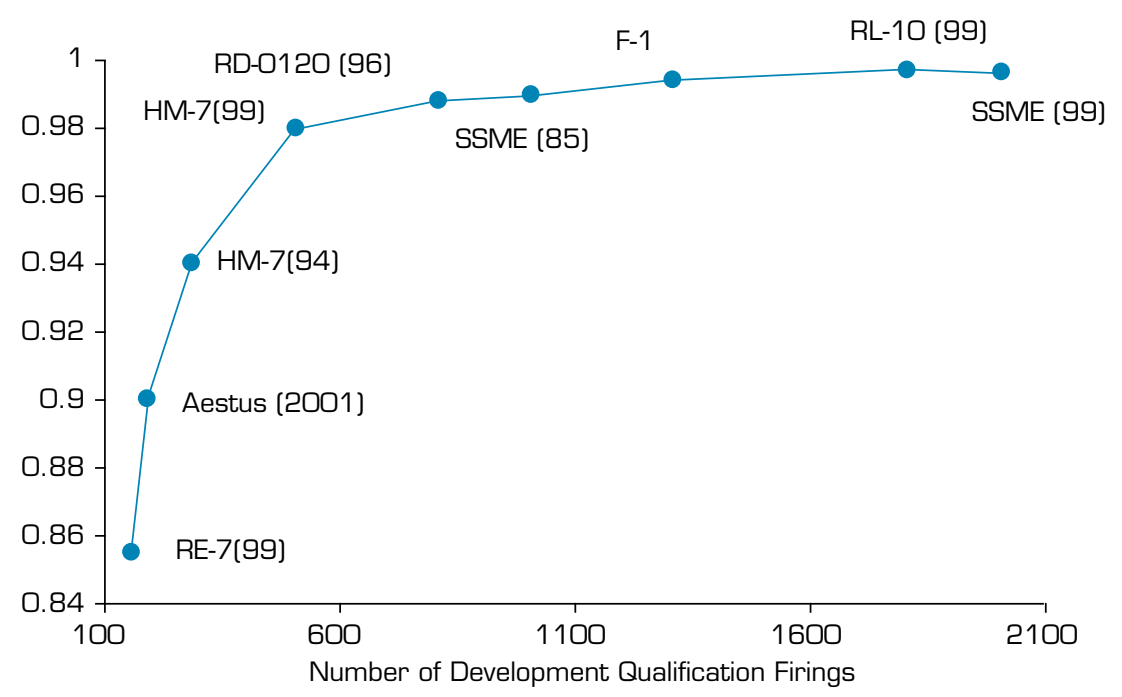

Figure 7. Reliability of LPRE - adapted from Koelle (2010). 
The experience of LPRE reliability aimed development efforts according to the experience of the leading LPRE developer countries (Russia, USA, Europe, and Japan) shows that at the beginning of flight testing there is a possibility to reach economically proved probability value of failure-free operation (at the confidence probability $\gamma=0.9$ ) about 0.96. Usage of the method of overstressed conditions and test modes (for instance, overrating of the nominal mode up to $20 \%$ ) would require not less than 56 tests of 19 test items (each with accumulating operation time equal to 3 flights operation time).

\section{SUMMARY OF TECHNOLOGICAL CHALLENGES}

This section shows a summary of technological challenges and how these problems were handled to avoid it in the future, in face of the limited financial resources. The lessons learned from the L75 project are compiled from project daily entries throughout the lifecycle, which were gathered from practical experience as well as through interviews with project team members and stakeholders.

The L75 project presented several technological challenges necessary to master liquid propulsion technology, such as the development of the turbopump and its components (rotors, turbine disk, Lox and ethanol pumps) operating at high speeds (up to $24,000 \mathrm{rpm}$ ) and critical temperatures of 800 and $-190^{\circ} \mathrm{C}$ at both tips; manufacture of the thrust chamber with regenerative cooling technology and the nozzle extension operating at temperatures up to $80{ }^{\circ} \mathrm{C}$; design of components such as thrust regulator and mixing ratio regulator, whose flow rates can reach $16 \mathrm{~kg} / \mathrm{s}$; and engine subsystems such as the ignition system, control system and fastening system.

To describe and predict engine behavior several mathematical models were established, which are: steady-state models, transient models and "extreme condition" models.

In general, steady-state models allow proper refinement of estimated characteristics, such as pressure drops along pipes, as well as allowing safety analyses of pressure and temperature at steady state along the engine. Additionally, the other objective is to study necessity of a servo actuator in the thrust regulator to enable reliable thrust regulation at different mixture ratios.

Transient models allow stability analyses, as well as theoretical performance of control laws that will be implemented. They are also used in safety analyses to check for pressure or temperature spikes (overshoots) along the engine that rise before achieving the steady-state regime.

The so-called "extreme condition" models are necessary to enable predictions of the engine behavior during starting or shutdown. In these regimes, the values of mass flow, pressure or temperature along several components, turbine rotation and composition and temperature of combustion gases are way outside of the nominal operational envelope, so new models for these conditions are required.

Other technological challenges during the project include specifying and purchasing components (for example, special seals and bearings) that operate in critical conditions at high thermal and mechanical loads; development of specific manufacturing processes (milling, brazing, welding and special alloys heat treatment); integration of the complete engine and its stage; consonance with the space standards and established systems engineering practices such as those contained in the technical standards of the SMAD (Wertz et al. 2011), ECSS (2009), MIL (US Department of Defense s.d.), NASA (2008), and ISO (2011), among others.

Table 6 provides the list of some others identified challenges, but not limited to them, related to the L75 project, possible impacts, and actions to handle them. 
Table 6. Some challenges related to the L75 project.

\begin{tabular}{|c|c|c|}
\hline Area/Challenge & Impact & Action \\
\hline $\begin{array}{l}\text { Planning / Not enough specialized } \\
\text { manpower to carry out the tasks }\end{array}$ & $\begin{array}{l}\text { This matter leads to delays in schedule. } \\
\text { Can become the project } \\
\text { execution unfeasible. }\end{array}$ & $\begin{array}{l}\text { Put smaller tasks as minimum to fulfill the } \\
\text { LPRE activities to avoid higher delays. } \\
\text { Partnership with stakeholders for hiring } \\
\text { and holding specialized manpower. } \\
\text { Permanent training. }\end{array}$ \\
\hline $\begin{array}{l}\text { Planning / Loss of technical knowledge } \\
\text { when a team member is transferred or } \\
\text { leaves the project }\end{array}$ & $\begin{array}{l}\text { Information losses, reworks, and delays } \\
\text { in project execution }\end{array}$ & $\begin{array}{l}\text { All teams' activities must be documented, } \\
\text { and all developed documents must be } \\
\text { maintained updated for the project team. } \\
\text { Partnership with stakeholders for holding } \\
\text { specialized manpower. }\end{array}$ \\
\hline $\begin{array}{l}\text { Planning / Linking the L75 } \\
\text { project to the other projects }\end{array}$ & $\begin{array}{c}\text { LPRE assumes uncertainties } \\
\text { and risks from other development } \\
\text { project, including unknown unknowns } \\
\text { (Kim, 2012). } \\
\text { Possibility of the LPRE project becoming } \\
\text { unviable. } \\
\text { Nonexecution of the project. } \\
\text { Nondesirable deliverables. }\end{array}$ & $\begin{array}{l}\text { Not linking to another } \\
\text { project development }\end{array}$ \\
\hline $\begin{array}{l}\text { Planning / Difficulty in } \\
\text { Maintaining the Team }\end{array}$ & $\begin{array}{l}\text { Difficulty to perform activities. } \\
\text { Can impair the technological domain. } \\
\text { Increase the execution time. }\end{array}$ & $\begin{array}{c}\text { Wages and benefits compatible with the } \\
\text { function, position, experience, and degree } \\
\text { of study. } \\
\text { Permanent training. }\end{array}$ \\
\hline $\begin{array}{c}\text { Technology / No service and acquisition } \\
\text { mechanisms necessaries } \\
\text { to meet the project deadlines, } \\
\text { cost, and scope }\end{array}$ & $\begin{array}{l}\text { Can become the project execution } \\
\text { unfeasible. } \\
\text { Can impair the technological domain. } \\
\text { Increase the execution time. }\end{array}$ & $\begin{array}{l}\text { Partnership with stakeholders for hiring } \\
\text { and holding specialized manpower. } \\
\text { Furthermore, foundation can access to } \\
\text { the equipment and acquisitions quicker } \\
\text { than public way. }\end{array}$ \\
\hline $\begin{array}{c}\text { Technology / Technological difficulties in } \\
\text { solving problems }\end{array}$ & $\begin{array}{l}\text { Increase the execution time. } \\
\text { Can drive new solutions. } \\
\text { Can increase the cost. }\end{array}$ & $\begin{array}{l}\text { Partnership with stakeholders for hiring } \\
\text { and holding specialized manpower. } \\
\text { Partnership with industries and } \\
\text { international agreements. } \\
\text { Consultant. }\end{array}$ \\
\hline
\end{tabular}

\section{SYSTEM ENGINEERING APPROACH}

System engineering is an interdisciplinary approach of engineering intends to focus on how to design and manage complex systems over their life cycles based on thinking principles to turn them into solutions that meet the requirements from any system. This approach puts together both technical, management fields and it is highly based on requirements (Halligan 2016). This technique was widely used in the $\mathrm{L} 75$ project.

The design of a propulsive system involves a trade-off among the potentially conflicting objectives: reliability, performance, risks, low recurring cost and low development cost. Following a focus on performance and the development of technologies, which brought engine performances remarkably close to their theoretical specific impulse limit, current developments have placed more emphasis on (Caisso et al. 2009):

- Reliability (reduced failure occurrence);

- Cost reduction (both direct - manufacturing processes and reduced parts number - as well as indirect: simplified operation and reduced system complexity);

- Improved endurance and life increase (with indirect benefit on reliability).

In the same way that the development of complex systems has several conflicting objectives, it is surrounded in a complex environment that involves some agents, i.e., companies, partnerships, research centers, test sites and launch center as well as the upper stage system, launch vehicle and satellite. In this environment, system engineering must be applied. Figure 8 summarizes these complex relationships of development. 


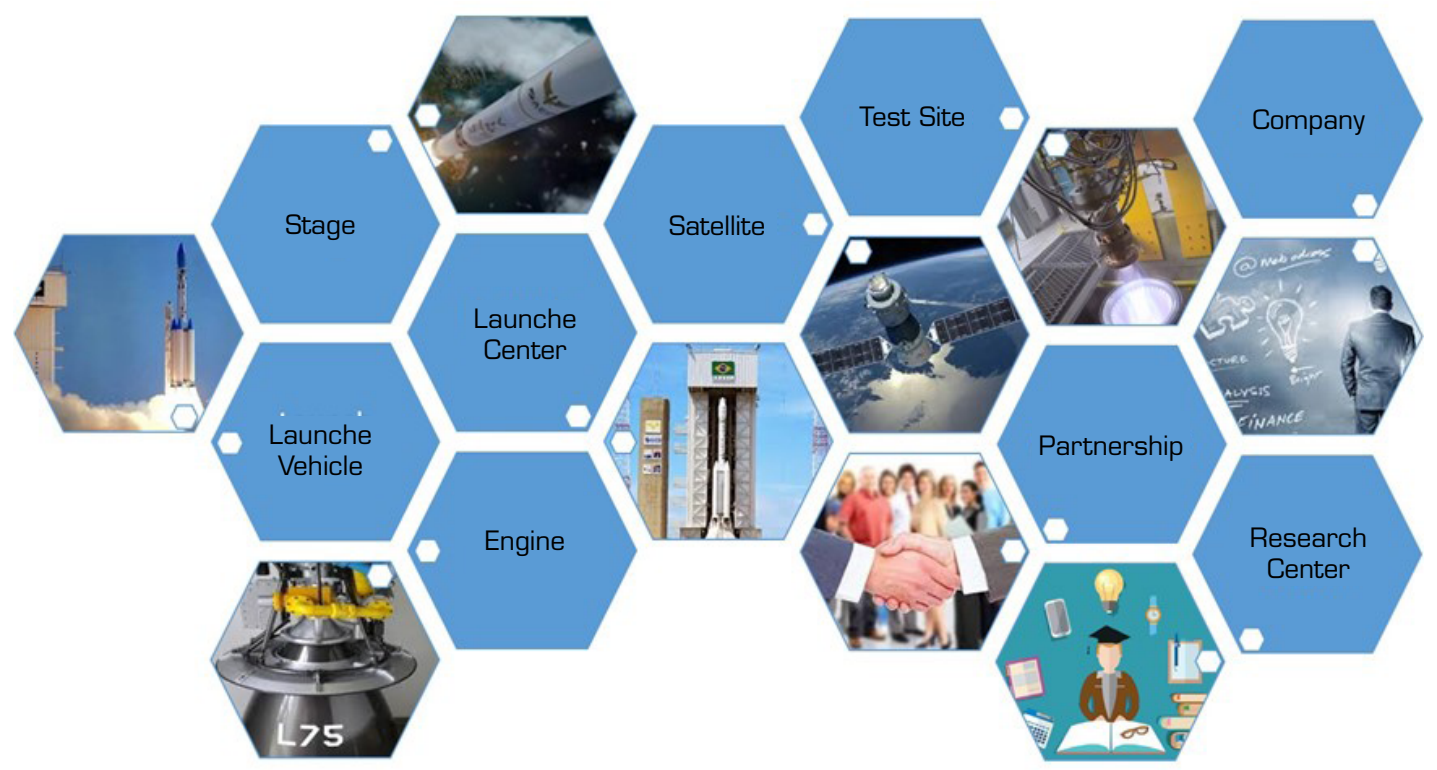

Figure 8. Complex relationship in a spatial environment.

There is increased recognition of the role of systems engineering in reducing the risk (technical, cost, and schedule) on complex space systems development and integration projects (Bone et al. 2009). The conceptual design stage is essential to the success of the total design process and the resulting vehicle system. It has been estimated that at least $80 \%$ of a vehicle's life-cycle cost depends on the concept of solution (Fig. 5), i.e., 80-90\% of the development cost of large systems is predetermined by only $5-10 \%$ of development effort has been completed.

Choices made during preliminary design, detail design, manufacturing, and operations (although essential) can have no more than a minor effect on the determining life-cycle cost. While poor detail design engineering can mess up a good concept, the best-detailed design engineering will not correct a flawed concept design and selection. The right concept of selection is critical in the spatial area (Blair et al. 2001). This means that solve problems and establish a solution to avoid substantial cost overrun. The main idea is solving problems and defines the solution at the beginning to avoid substantial cost and time overrun. Figure 9 displays the percentage of system life-cycle cost and total cost as a function of design phases and TRL. Tables 7 and 8 show the TRL definitions and main project reviews, based on European Commission for Space Standardization (ECSS).

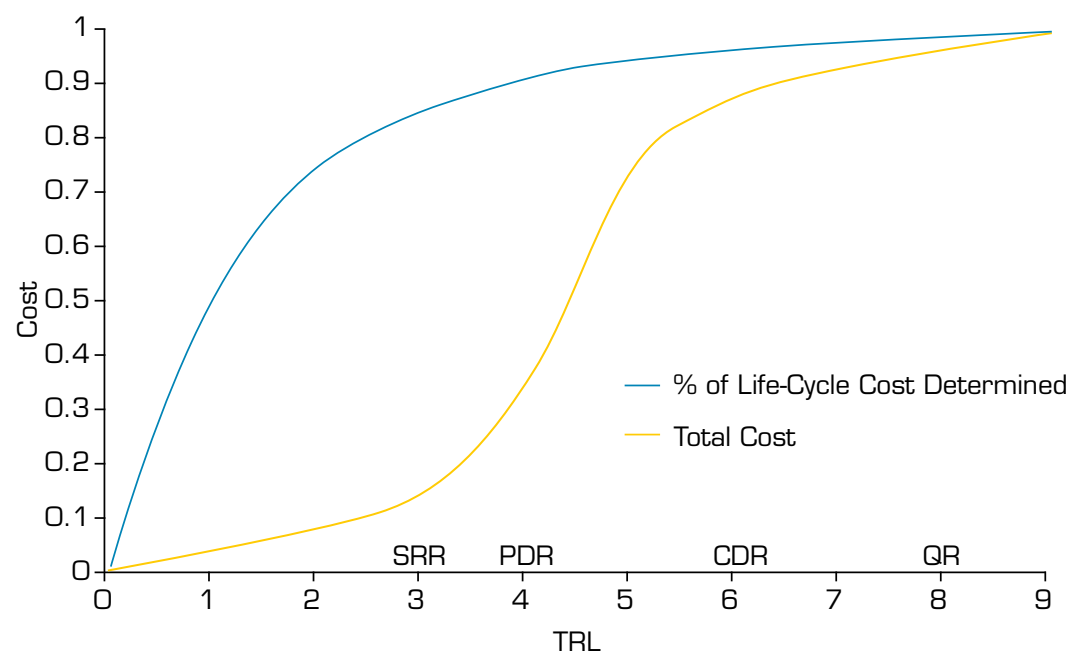

Figure 9. Percentage of system life cycle cost determined and total cost as a function of design phases and TRL - adapted from Blair et al. (2001). 
Table 7. TRL definitions.

\begin{tabular}{cc}
\hline TRL & Definition of each Technical Readiness Level (TRL) \\
\hline 1 & Basic principles observed and reported \\
\hline 2 & Potential application validated \\
\hline 3 & Proof-of-concept demonstrated, analytically and/or experimentally \\
\hline 4 & Component laboratory validated \\
\hline 5 & Component validated in simulated or real space environment \\
\hline 6 & System adequacy validated in simulated environment \\
\hline 7 & System adequacy validated in space \\
\hline 8 & System complete and qualified \\
\hline 9 & System proven in operational environment (competitive \\
\hline
\end{tabular}

Table 8. Main project reviews.

\begin{tabular}{cc}
\hline & Main Project Review \\
\hline SRR & System Requirements Review \\
\hline PDR & Preliminary Design Review \\
\hline CDR & Critical Design Review \\
\hline QR & Qualification Review
\end{tabular}

Based on TRL, technologies that have been demonstrated in a laboratory environment at level 3, are further developed and tested via integrated demonstrators to raise them to TRL 6. Once a technology has reached level 6, much of the risk linked to using new technology in a space environment has been mitigated. It can be transferred to development up to flight (TRL 9) with optimized cost and schedule. Technologies can be selected on their potential to reduce cost, improve performance, improve reliability, or on their ability to fulfill the specific needs of an identified system, demonstrator, or mission. Integrated demonstrators are built by combining multiple technologies into one system or subsystem so that the industry can use the technology with confidence.

During the $\mathrm{L} 75$ project execution period, a focus was concentrated on the formation of a highly trained technical team, consolidation of the project documentation, consolidation of an industrial base for manufacture of engine components, implantation or search of test facilities for its components and establishment of international partnership to supply the deficiencies in knowledge and/or equipment that were not available in the country, which succeeded increasing the TRL for the liquid propulsion technology in Brazil to 3.

This development led to design, manufacture, development models testing for its components, and construction of some test facilities, besides many publications in journals and congresses.

\section{ENGINE'S DEVELOPMENT STRATEGY}

The engine's development strategy to face the LPRE problems was primarily based on: a) the space standards [SMAD (Wertz et al. 2011), ECSS (2009), MIL (US Department of Defense s.d.), NASA (2007; 2008), ISO (2011), and others]; b) the requirements arose from engine, subsystems and components; c) the definition of development, engineering and qualification models of the parts, subsystems and engine components to verify compliance with the requirements (Table 9); d) partnerships with research centers, industries, foundation, and universities; e) a verification program was established through a development and verification plan, according to engine specifications, considering the methods of verification (test, analysis, design review, inspection), models and requirements to be verified during the development. 
Table 9. L75 engine's development strategy.

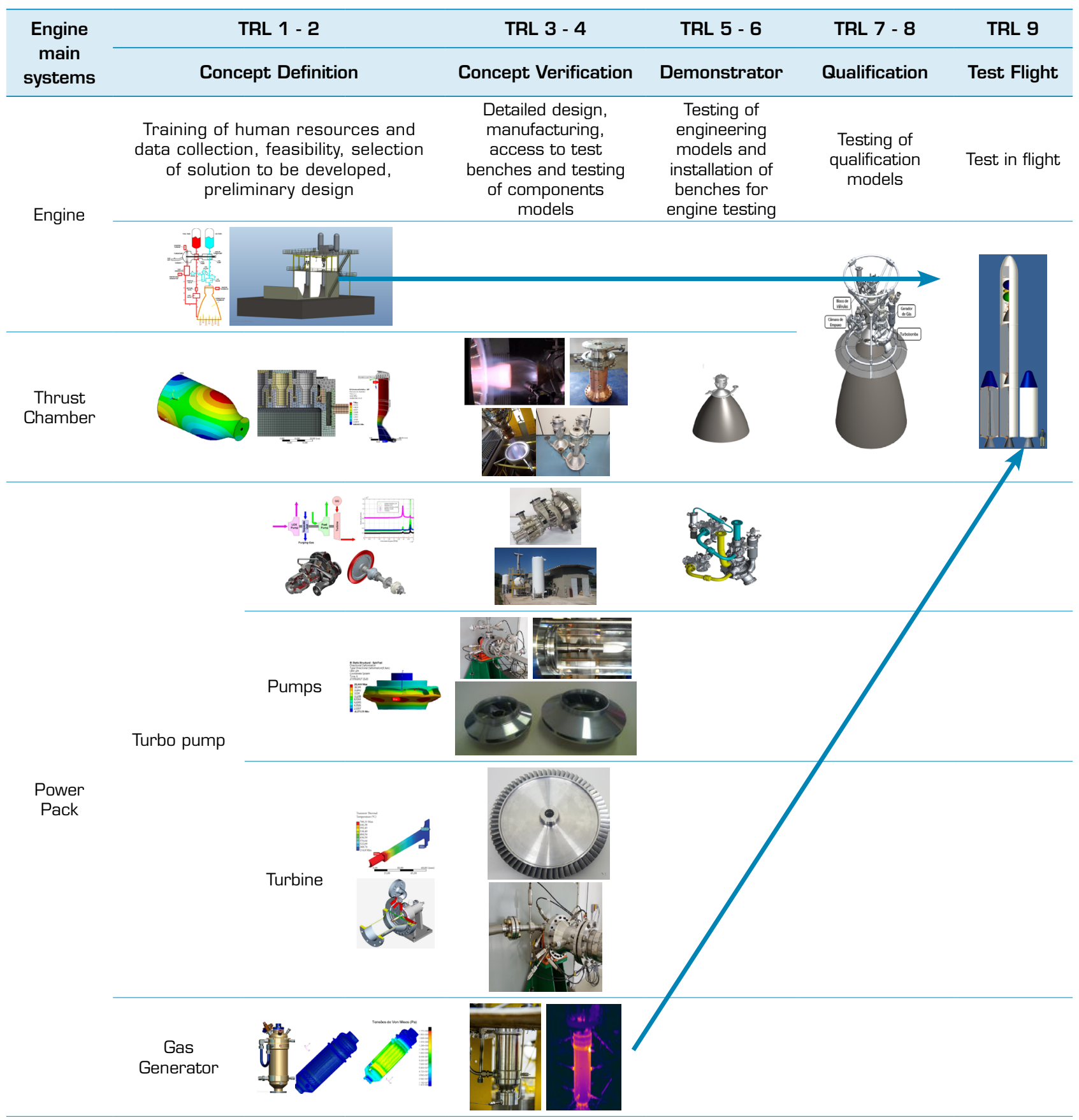

The work during the first phase lasting from 2012 to 2017 has been mainly focused on the consolidation of the engine's development plan, the definition of technical and functional requirements for subsystems, manufacturing demonstration as well as definition, layout, and realization of test facilities. The first phase was accomplished by design, manufacturing, and tests of first predevelopment hardware for combustion chamber and injector, gas generator, ignition systems and turbopump starter, as well as for turbopump components - inducer, impeller, Lox and fuel pump, and turbine.

System studies basically covered engine cycle analysis and freezing of the engine technical specification. For the thrust chamber assembly, component design and manufacturing were performed culminating in successful testing of a full-scale development model (DM1). DM1 tests have been performed at DLR's test facility in Lampoldshausen/Germany, and a subscale predevelopment 
model was manufactured for injector element optimization and cooling channels evaluation, tests have been performed at IAE's test facility in São José dos Campos/Brazil. For DM1 two different injector heads were tested proving stable combustion in transient and steady state conditions (Pfützenreuter et al. 2017).

In parallel to the thrust chamber assembly development, turbopump activities have been focused on the design, manufacturing, and testing of a DM of its components Lox pump, fuel pump, and turbine in Brazil using model fluids as water and gaseous nitrogen. Those tests provided inputs for the first turbopump development model. Last activities in Germany concentrate on design and manufacturing of German designed turbopump demonstration components, as an alternative solution for the turbopump of the L75 engine. The first Germany turbine model was tested in Brazil in July 2019.

The development of the L75 engine requires numerous enabling products, among which are test benches. They are necessary for the development and qualification of engine subsystems and components, such as injectors, valves, pumps, turbine, gas generator, turbine, thrust chamber and complete engine, to name a few. During the project execution, engineering effort was greater than $700,000 \mathrm{~h}$, which allowed the elaboration of 395 technical reports and more than 2500 technical drawings along to the duration of the phase 1 (Table 3 ).

The largest test bench for LPRE in Brazil is at IAE and has capacity for test engines up to $20 \mathrm{kN}$, using Lox and ethanol. This bench is used in the L75 engine gas generator project and is sufficient for both tests of development and qualification of this component. In Brazil, however, there are no facilities for testing integrated liquid propellant rocket engines for $100 \mathrm{kN}$ thrust range.

The P8 test bench at Lampoldshausen test complex was used for research and development of rocket engine technologies, it was chosen to carry out development tests of the L75 Engine TCA. The P8 is a proprietary test bench shared by CNES, DLR and Ariane Group. Its use for TCA test campaigns depends on the contracting of the DLR through Ariane Group, and the availability of test windows must be negotiated with other projects of their owners. In addition, there is no test bench available in Germany capable of testing the integrated L75 engine or its power pack. Considering that, the construction of a test bench (BE100kN) in Brazil to enable tests of the thrust chamber, power pack and the integrated engine in a single installation is much more advantageous than contracting them abroad.

In addition to the qualification of Brazilian labor and the return to the national industry promoted by the construction of the BE100kN, the logistics in the development of the L75 and other engines with up to $100 \mathrm{kN}$ of thrust become immensely advantageous for the IAE because it does not need to wait or negotiate test windows or accommodate delays in campaigns abroad, which impact the issuance of mission ordinances, purchase of tickets, payment of per diem and clearance of rocket engine components at customs. Preliminary studies indicate a total of 131 weeks using BE100kN and 350 tests until the start of L75 qualification.

The work during Phase 1 (Table 3), lasting from 2012 to 2017, has been mainly focused on the consolidation of the engine's development plan, the definition of technical and functional requirements for subsystems, manufacturing demonstration as well as definition, layout, and realization of test facilities. The first phase was accomplished by design, manufacturing, and tests of first predevelopment hardware for combustion chamber and injector, gas generator, ignition systems and turbopump starter, as well as for turbopump components - inducer, impeller, Lox and fuel pump, and turbine. System studies basically covered engine cycle analysis and freeze of the engine technical specification.

In addition to the testing campaign on the P8, the partnership with DLR made it possible to review the L75 project by internationally renowned specialists; sharing of technical activities; crosscheck of the pumps and turbine design by parallel development in both countries; access to highly qualified consultants; access to suppliers of critical components not available in Brazil; access to test suppliers not available in Brazil; access to technical universities (Technical University of Munich and Technical University of Kaiserslautern) to carry out specific developments.

\section{CONCLUSIONS}

The execution of the L75 project up to now has proven that IAE has the capability to develop a LPRE for the application in a launcher system. To mitigate risk, IAE decided, from the beginning, to involve foreign, experienced partners. Cooperation with 
DLR and German industry was initiated, and the result is a further proof that a partnership model involving one of the pioneer countries in space business is key factor to manage difficulties and to avoid basic mistakes.

The conclusion of the L75 project requires investments of the order of US\$ 60 million, along an eight-year period. However, due to the lack of funds from the Brazilian Government, the project has been interrupted. As a result, German investments were also suspended and until this situation changes the project is halted.

\section{AUTHORS' CONTRIBUTION}

All the authors contributed equally to this paper.

\section{DATA AVAILABILITY STATEMENT}

All dataset were generated or analyzed in the current study.

\section{FUNDING}

Agência Espacial Brasileira

\section{ACKNOWLEDGEMENTS}

The authors wish to thank, the IAE for supporting the activities performed in L75 project and DLR for cooperation.

\section{REFERENCES}

[AEB] Agência Espacial Brasileira (1998) Programa Nacional de Atividades Espaciais 1998 - 2007. Brasília: AEB.

[AEB] Agência Espacial Brasileira (2005) Programa Nacional de Atividades Espacial, Brasília: AEB.

[AEB] Agência Espacial Brasileira (2012) Programa Nacional de Atividades Espaciais: PNAE: 2012 - 2021. Brasília: AEB.

[AEB] Agência Espacial Brasileira (2020) VS-50. [accessed Sep 30 2020]. https://www.gov.br/aeb/pt-br/programa-espacialbrasileiro/transporte-espacial/vs-50

[ECSS] European Cooperation for Space Standardization (2009) ECSS-M-ST-10C - Project planning and implementation. Noordwijk: ECSS.

[NASA] National Aeronautics and Space Administration (2007) NASA Systems Engineering Handbook. Washington: NASA.

[NASA] National Aeronautics and Space Administration (2008) NASA Cost Estimating Handbook Version 4.0. Washington: NASA.

[NTSB] National Transportation Safety Board (2006) NTSB Review of Aircraft Accident Data: U.S. General Aviation, Calendar Year 2001. NTSB/ARG-06/01. Washington: NTSB. 
[PMI] Project Management Institute (2013) Guide to the Project Management Body of Knowledge. Project Management Institute.

Almeida DS, Pagliuco CMM, Souza BRD, Burkhardt H, Lippert C, Preuß A, Langel G (2016) Cooperative Development of L75 LOX Ethanol engine: Current Status with Focus on Capacitive Chamber Testing. Rome, Italy.

Blair JC, Ryan RS, Schutzenhofer LA, Humphries WR, inventors; Vehicle Design Process: Characterization, Technical Integration, and Lessons. 2001 May 1. Launch Vehicles and Launch Operations. Work of the US Gov. Public Use Permitted.

Boeing (2006) Statistical Summary of Commercial Jet Airplane Accidents: Worldwide operations 1959 - 2005. [accessed Jul 2 2020]. https://www.skybrary.aero/bookshelf/books/3810.pdf

Bone M, Cloutier RL, Gill E, Verma D (2009) A Case Study: Application of the Systems Engineering Modeling in the early phases of a Complex Space System Project. Paper presented 7th Annual Conference on Systems Engineering Research 2009. CSER; Loughborough, UK.

Caisso P, Souchier A, Rothmund C, Alliot P, Bonhomme C, Zinner W, Parsley R, Neill T, Forde S, Starke R, et al. (2009) A liquid propulsion panorama. Acta Astronautica 65(11-12):1723-1737. https://doi.org/10.1016/j.actaastro.2009.04.020

Ernst R (2014) Liquid Rocket Analysis (LiRA): development of a liquid bi-propellant rocket engine design, analysis and optimization tool (Master thesis). Delft: Delft University of Technology.

Haeseler D, Goetz A, Froehlich A (2000) Non-toxic propellants for future advanced launchers propulsion systems. Paper presented 36th AIAA/ASME/SAE/ASEE Joint Propulsion Conference and Exhibit. AIAA; Las Vegas, USA. https://doi. org/10.2514/6.2000-3687

Haidn OJ (2008) Advanced Rocket Engines. In: OTAN, editor. Advances on Propulsion Technology for High-Speed Aircraft Neuilly-sur-Seine: OTAN. p. 6-1-6-40.

Halligan R (2016) Systems Engineering Course. In: Systems Engineering Training \& Consulting for Technology-Based Projects and Product Developments. Melbourne: Project Performance International.

[ISO] International Organization for Standardization (2011) ISO 11893:2011 Space systems — Programme management — Project organization. Geneva: ISO.

Kessaev JV (1997) Theory and Calculation of Liquid-Propellant Engines. In: Fundamental Course in Engine Design. São José dos Campos: CTA/IAE.

Kim SD (2012) Characterizing unknown unknowns. Paper presented at PMI’ Global Congress 2012. PMI; Newtown Square, USA.

Koelle DE (2010) Handbook of Cost Engineering for Space Transportation Systems. Ottobrunn: TransCostSystems.

Langel G (2018) Challenges and Engineering Tasks in Rocket Propulsion. São José dos Campos.

Niwa M, Yoshino T (1997) Propulsão Líquida no Brasil. XIV Congresso Brasileiro de Engenharia Mecânica. Bauru, Brazil.

Parnell GS, Driscoll PJ, Henderson DL (2011) Decision Making in System Engineering and Management. Hoboken: John Wiley \& Sons.

Pfützenreuter L, Burkhardt H, Lippert C (2017) L75 LOx ethanol engine: current status of thrust chamber and turbo pump cooperative development. Paper presented 53rd AIAA/SAE/ASEE Joint Propulsion Conference. AIAA; Atlanta, USA. https://doi.org/10.2514/6.2017-4752

Santos EA, Alves WF, Prado ANA, Martins CA (2011) Development of test stand for experimental investigation of chemical and physical phenomena in Liquid Rocket Engine. J Aerosp Technol Manag 3(2):159-170. https://doi.org/10.5028/ jatm.2011.03021111 
Sutton GP (2006) History of liquid propellant rocket engines. Virginia: AIAA.

Torres MFC, Almeida DS, Krishna YSR, Silva LA, Shimote WK (2009) Translation: Liquid Propulsion at IAE: Vision of the activities and future perspectivies. J Aerosp Technol Manag 1(1):99-106. https://doi.org/10.5028/jatm.2009.010199106

US Department of Defense. United States Military Standard. [accessed Jul 2 2020]. Site

Wertz JR, Everett DF, Puschell JJ (2011) Space mission engineering: the new SMAD. Portland: Microcosm Press.

Zandbergen BTC (2000) Modern liquid propellant rocket engines, 2000 Outlook. https://doi.org/10.13140/2.1.4640.0003 